DANMARKS GEOLOGISKE UNDERS $\emptyset$ GELSE · SERIE A · NR. 14 MILJØMINISTERIET · Geological Survey of Denmark

\title{
Palynology of the Middle Jurassic Lower Graben Sand Formation of the U-1 well, Danish Central Trough
}

BY

TORSTEN HOELSTAD

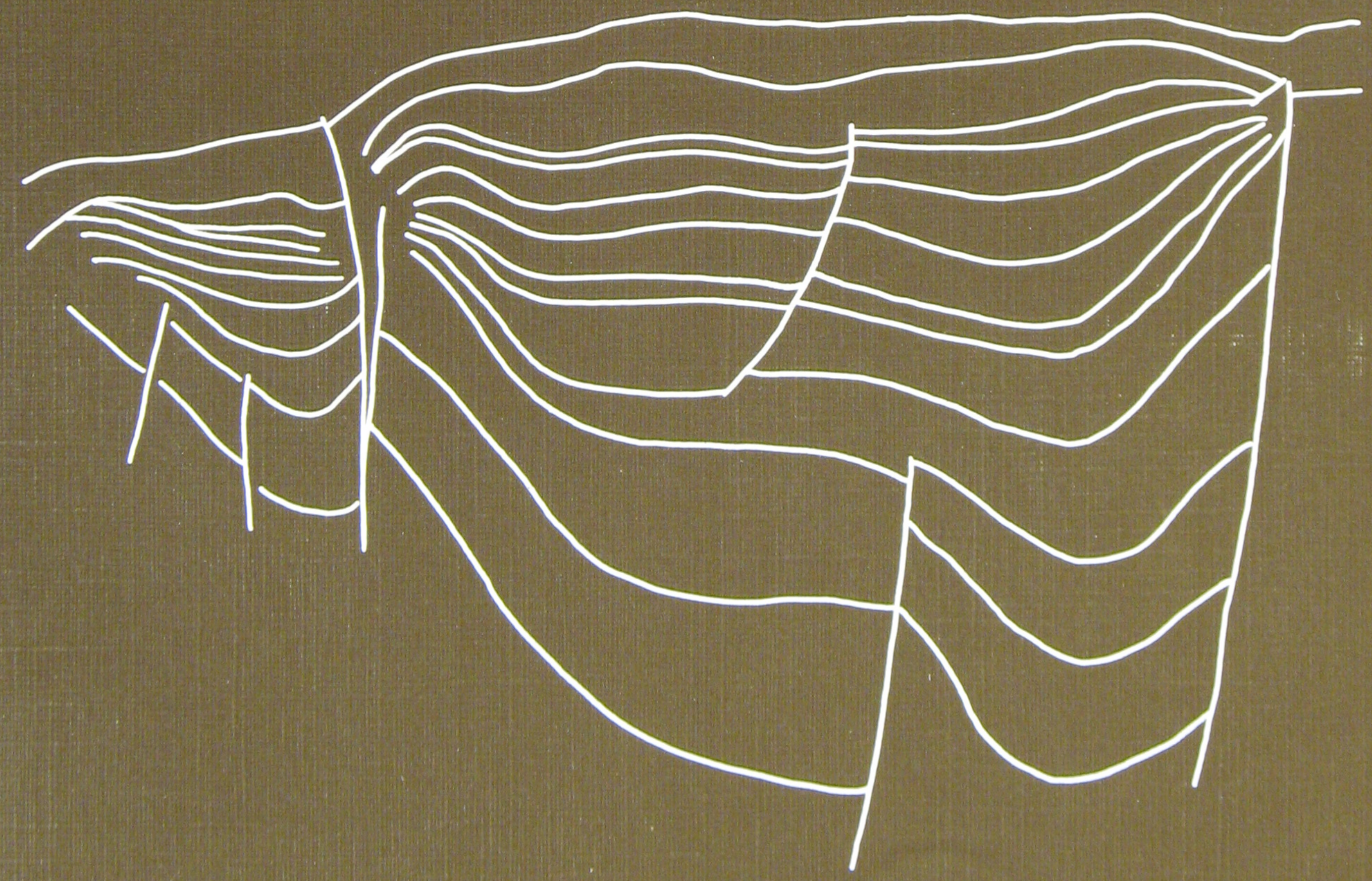


PH DANMARKS GEOLOGISKE UNDERSøGELSE · SERIE A · NR. 14 MILJØMINISTERIET · Geological Survey of Denmark

\section{Palynology \\ of the Middle Jurassic \\ Lower Graben Sand Formation of the U-1 well, \\ Danish Central Trough}

BY

TORSTEN HOELSTAD

I kommission hos C. A. Reitzels forlag · København 1986 


\section{A contribution to \\ EFP-83 project: \\ Jurassic-Lower Cretaceous stratigraphy \\ and basin development of the Danish North Sea Sector.}

Key-words:

Palynostratigraphy, Palynofacies, Middle Jurassic, Callovian, Lower Graben Sand Formation, Denmark, North Sea, Sidewall cores.

With 2 plates

Vignette:

East-West section through the Tail End Graben

DGU Serie A nr. 14

ISBN 87-421-0747-4

ISSN 0901-0270

Oplag: 1200

Tryk: AiO Tryk as, Odense

Tegning: Helle Zetterwall

Dato: 1986-12-01

Torsten Hoelstad, nuvarende adresse: Stratlab as,

Hvamveien 4, boks 175, 2013 Skjetten, Norge

Redaktion: Leif Banke Rasmussen

(C) Danmarks Geologiske Undersøgelse,

Thoravej 31, DK-2400 København NV 


\section{Preface}

The present paper is one of several reports issued as the result of a research project carried out by the Geological Survey of Denmark in cooperation with the Geological Institute at the University of Copenhagen. The project has been financed by special contributions given by the Ministry of Energy for the period 1st of August 1983 to 31st of December 1985.

The project was entitled "Jurassic - Lower Cretaceous stratigraphy and basin development of the Danish North Sea sector". It has been decided to limit the study area to the Danish Central Trough, and furthermore the effort has been concentrated on the Middle Jurassic, the Upper Jurassic, and the Lower Cretaceous.

The scope of the project was to coordinate analyses of the stratigraphy, facies development and burial history in order to create a basis for predicting possible occurrences of reservoir rocks. The following reports (including the present one) will be printed in the series published by the Geological Survey of Denmark and issued in 1986 and 1987:

Frandsen, N.: Middle Jurassic deltaic and coastal deposits in the Lulu-1 well of the Danish Central Trough.
Heilmann-Clausen, C.: Lower Cretaceous dinoflagellate biostratigraphy in the Danish Central Trough.

Hoelstad, T.: Palynology of the Middle Jurassic Lower Graben Sand Formation of the U-1 well, Danish Central Trough.

Hoelstad, T.: Palynology and palynofacies analysis of the Middle Jurassic to Lower Cretaceous in the Danish Central Trough.

Jensen, T. F., Holm, L., Frandsen, N. \& Michelsen, O.: Jurassic - Lower Creataceous lithostratigraphic nomenclature for the Danish Central Trough.

Møller, J. J.: Seismic structural mapping of the Middle and Upper Jurassic in the Danish Central Trough.

Poulsen, N.: Callovian (Jurassic) to Ryazanian (Cretaceous) dinoflagellate biostratigraphy of the Danish Central Trough.

Thomsen, E.: Lower Cretaceous nannofossil biostratigraphy in the Danish Central Trough.

Vejbæk, O. V.: Seismic stratigraphy of the Lower Cretaceous in the Danish Central Trough.

Vejbæk, O. V., Frandsen, N., Holm, L., Jensen, T. F., Møller, J. J. \& Michelsen, O.: Jurassic - Lower Cretaceous of the Danish Central Trough; - depositional environments, tectonism, and reservoirs.

DGU, 30th December 1985

Olaf Michelsen 


\section{Contents}

Abstract .............................

Introduction........................ 8

Material and methods ................. 10

Palynological description of samples investigated 11

Systematical remarks.................... 13

Palynostratigraphy $\ldots \ldots \ldots \ldots \ldots \ldots \ldots \ldots, 14$

Environmental evaluation. . .
Palynofacies analysis .................. 17

Lithology ............................ 17

Depositional environment................. 17

Conclusion.......................... 19

Acknowledgements ................... 20

References........................ 21

Plates $1-2 \ldots \ldots \ldots \ldots \ldots \ldots \ldots \ldots \ldots . .22-25$ 


\section{Abstract}

Twentyone sidewall core samples from the lower 56 metres of the Lower Graben Sand Formation in the U-1 well are described with respect to their kerogen content and microflora in order to gain a better understanding of the depositional environment and the age relations. Based on e.g. the inconsistent dinoflagellate cyst occurences, marginal marine conditions are concluded. The dinoflagellate cysts Pareodinia prolongata,
Acanthaulax senta, Scriniodinium crystallinum, Energlynia acollaris, Wanaea thysanota and Hystrichogonyaulax cladophora and the recovered palynomorph assemblage in general permit an age determination as follows: $21 \mathrm{~m}$ Callovian undifferentiated, $7.9 \mathrm{~m}$ latest Middle Callovian - earliest Late Callovian, $6.1 \mathrm{~m}$ latest Late Callovian and $21 \mathrm{~m}$ latest Late Callovian? - earliest Early Oxfordian. 


\section{Introduction}

The primary aim of the present investigation is to focus on the palynostratigraphy and the palynofacies of the
Lower Graben Sand Formation (Jensen et al. 1986) of the $\mathrm{U}-1$ well.

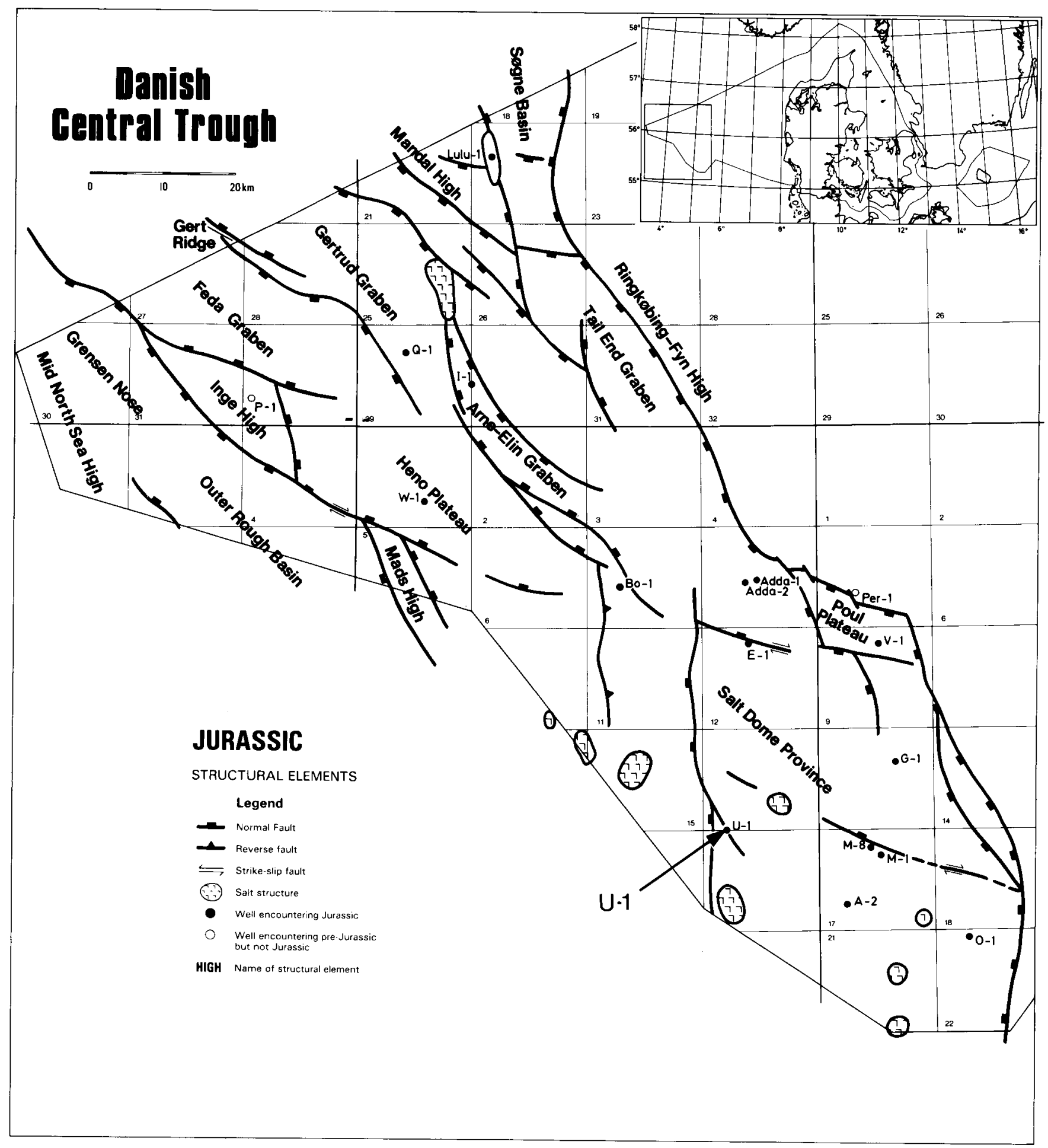

Fig. 1. Location of the U-1 well. (Figure from Moller 1986) 
The Lower Graben Sand Formation is of interest from the point of view of its hydrocarbon reservoir potential. Precise datings and environmental interpretations are of prime value in estimating its stratigraphic and palaeogeographic distribution and thus an aid in future explorations. The depositional environment and the age of the Lower Graben Sand Formation in general and in the $U-1$ well in particular have been dealt with previously by e.g. Michelsen (1976), Koch, Holm \& Michelsen (1982), Koch (1983) and Frandsen, Hoelstad \& Mikkelsen (1985).

Based on biostratigraphy and lithostratigraphy Michelsen (1976) provisionally assigned a Middle Jurassic age to the Lower Graben Sand Formation in the U-1 well. Koch et al. (1982) mention a palynostratigraphically based Bathonian - Bajocian age for the formation in the U-1 well. The depositional environment favoured by Koch et al. (1982) is that of a prograding delta (pro-delta clays and distributary mouth bar sands) whereas Koch (1983) suggests a braided river plain. A marine influenced flood plain environment is proposed by Frandsen et al. (1985). Based on palynology Frandsen et al. (1985) refer the upper part of the Lower Graben Sand Formation in the U-1 well to the Callovian.

The U-1 well is located in the southern part of the Danish Central Trough, about $40 \mathrm{~km}$ west of the Ringkøbing-Fyn High, in the Salt Dome Province, fig. 1. 


\section{Material and methods}

A total of 21 sidewall core (SWC) samples from the interval $10875 \mathrm{ft}$. $-11059 \mathrm{ft}$. b. KB were investigated. The upper boundary of the Lower Graben Sand Formation is placed at $10853 \mathrm{ft}$. (Jensen et al. 1986). Thus the present investigation does not include the uppermost $22 \mathrm{ft}$. of the formation.

The samples received standard palynological treatment. The palynofacies analysis rests on an examination of slides prepared for Finn Bertelsen during the period 1978-79, whereas the biostratigraphic data are supplemented by observations made on slides from samples re-prepared in the autumn of 1984. The slides are identified by depth and number and are stored at the Geological Survey of Denmark, Thoravej 31, 2400 Copenhagen NV, Denmark. The coordinates given for specific specimens are equivalent to those on the grid of the England Finder slide (manufacturer: Graticules Ltd., London).
The classification employed concerning the kerogen types is that of Burgess (1974), and the terminology follows that of Bujak, Barss \& Williams (1977). The four main categories are amorphogen (unorganized, structureless organic material), phyrogen (cuticle, cortex, spores/pollen and dinoflagellate cysts), hylogen (nonopaque fibrous material of woody origin, sensu stricto) and melanogen (opaque organic material). Further descriptions of the various terms and categories used are found in Bujak et al. (1977), Manum \& Throndsen (1978) and Perry, Whitley and Simpson (1983). A detailed account of the counting method employed for palynofacies analysis is given in Hoelstad (1986).

The original depth unit is retained, thus all depths are given in feet below KB. 


\section{Palynological description of samples investigated}

\section{SWC sample $10875 \mathrm{ft}$. (slide S1 901)}

Relatively large $(60-100 \mu \mathrm{m})$ particles of cortex, cuticle and melanogen dominate the kerogen content. Although sparsely represented, nine spore/pollen taxa and at least three dinoflagellate cyst taxa were recognized. A single well-preserved specimen of the dinoflagellate cyst Scriniodinium crystallinum has been recovered, plate 2, fig. 5 (England finder coord. Q 54/3).

\section{SWC sample 10881 ft. (slide S1 903)}

Lath shaped melanogen and hylogen, cortex and cuticle dominate. Fifteen spore/pollen taxa were recognized. Dinoflagellate cysts are present, but only Gonyaulacysta jurassica has been identified. One specimen of the green alga Tasmanites was recovered. The sample is relatively well sorted.

\section{SWC sample $10900 \mathrm{ft}$. (slide S1 904)}

The kerogen content is sparse (less than 200 particles/ slide). Four spore/pollen taxa were recognized. No unquestionable dinoflagellate cysts are present.

\section{SWC sample 10914 ft. (slide S1 906)}

The sample is dominated by moderately large (50$80 \mu \mathrm{m})$, equidemensional particles of melanogen. Equally sized and shaped particles of cortex and cuticle dominate the phyrogen fraction. Seven spore/pollen taxa were recognized. No dinoflagellate cysts were found.

\section{SWC sample 10938 ft. (slide S1 867)}

Ten spore/pollen taxa were recognized, and a fragment of the dinoflagellate cyst Rigaudella aemula. Preservation of palynomorphs is poor. The phyrogen fraction is clearly dominated by cortex and cuticle. Palynomorphs occur only sporadically. Resin is present.

\author{
SWC sample $10940 \mathrm{ft}$. (slide S1 869)
}

The microflora is somewhat richer than that of sample $10938 \mathrm{ft}$. (13 spore/pollen taxa and more than three dinoflagellate cyst taxa). Among the dinoflagellate cysts only a fragment of Rigaudella aemula has been identified. The main elements of the phyrogen fraction are cortex and cuticle. The palynomorph preservation and representation are poor.

\section{SWC sample 10942 ft. (slides S1 872 and $1273 D 3 / D G U)$}

Compared to sample $10940 \mathrm{ft}$. there is a further increase in the number of palynomorph taxa (16 spore/ pollen taxa and eight dinoflagellate cyst taxa). Cortex and cuticle dominate the sample. Recognized dinoflagellate cysts are: Rigaudella aemula, Pareodinia ceratophora and Acanthaulax senta. Preservation is moderate. Resin is present.

SWC sample 10944 ft. (slides S1 873 and $1274 \mathrm{D3} / \mathrm{DGU})$

Among the eight dinoflagellate cyst taxa observed are: Pareodinia prolongata, Acanthaulax senta and Sentusidinium pilosum (slide 1274 D3/DGU, Engl. finder coord. K 38/1). Preservation is moderate. Resin is present. The sample is dominated by cortex and cuticle. Fifteen spore/pollen taxa were recognized, Deltoidospora spp. and Perinopollenites elatoides being the main elements of the assemblage.

\section{SWC sample 10962 ft. (slide S1 877)}

The main constituent is cortex and cuticle. The microflora has not been analysed.

\section{SWC sample $10964 \mathrm{ft}$. (slides S1 880 and $1275 C 2 / D G U)$}

The phyrogen fraction is dominated by cortex and cuticle. Eight spore/pollen taxa and more than six dinoflagellate cyst taxa were recognized. The dinoflagellate 
cyst Energlynia acollaris occurs commonly (slide 1275 C2/DGU, Engl. finder coord. X 55/1, N 60/1 and S 37/ 3). A fragment of Wanaea thysanota was found. Resin is common. Preservation of the palynomorphs is generally poor

\section{SWC sample $10966 \mathrm{ft}$. (slides S1 881 and $1276 \mathrm{D} 3 / \mathrm{DG} U)$}

Seven spore/pollen taxa and six dinoflagellate cyst taxa were seen. A slight decrease in occurrence of Energlynia acollaris compared to sample $10964 \mathrm{ft}$. is detectable. The sample is dominated by cortex and cuticle. Preservation of palynomorphs is generally poor. Resin is present.

\section{SWC sample $10970 \mathrm{ft}$. (slides S1 884 and $1277 \mathrm{C} 2 / \mathrm{DGU})$}

Spores and pollen are represented by eight taxa, dinoflagellate cysts by at least nine taxa. Acanthaulax senta was recovered (slide 1277 C2, Engl. finder coord. S 31/ $2)$. The phyrogen fraction is mainly cortex and cuticle. Preservation is moderate. Resin is common.

\section{SWC sample $10976 \mathrm{ft}$. (slide S1 887)}

Equidimensional, relatively large $(80-100 \mu \mathrm{m})$ particles of melanogen constitute almost the entire content of kerogen. Resin is common.

\section{SWC sample 10978 ft. (slide S1 889)}

Bisaccate pollen dominates phyrogen fraction. No unquestionable dinoflagellate cysts were found. Kerogen content in general is sparse, about 700 grains/slide.

\section{SWC sample 10990 ft. (slide S1 909)}

Twelve spore/pollen taxa and more than eight dinoflagellate cyst taxa were recognized. Among the dinoflagellate cysts are: Energlynia acollaris, Wanaea thysanota (Engl. finder coord. H 49/4) and the only specimen recovered of Netrelytron stegastum (Engl. finder coord. R 63/3). Phyrogen is dominated by cortex and cuticle. Preservation is poor. The pollen taxon Araucariacites australis is common.

\section{SWC sample $11008 \mathrm{ft}$. (II) (slide S1 911)}

The dominating kerogen type is granular amorphogen. No dinoflagellate cysts have been seen. Resin is present. The spore/pollen content has not been recorded. However, it is estimated that less than five taxa are present.

\section{SWC sample 11016 ft. (slide S1 913)}

The sample is dominated by large $(80-120 \mu \mathrm{m})$, equidimensional particles of melanogen and cortex and somewhat smaller lumps of amorphogen. Spores and pollen are extremely sparse. Dinoflagellate cysts are absent. Resin is present.

\section{SWC sample $11020 \mathrm{ft}$. (II) (slide S1 916)}

No certain evidence of dinoflagellate cyst presence was found. The spore/pollen assemblage is dominated by Deltoidospora spp. and Araucariacites australis. Besides those, four other taxa were recognized. The phyrogen fraction is mainly cortex and cuticle. Granular amorphogen is the main kerogen element.

\section{SWC sample 11044 ft. (slide S1 919)}

The phyrogen fraction contains, besides the dominating cortex and cuticle, a relatively rich spore/pollen flora (16 taxa were found). Araucariacites australis and Deltoidospora spp. occur most frequently. No certain evidence for the presence of dinoflagellate cysts was found. Resin is present.

\section{SWC sample 11054 ft. (slide S1 921)}

The sample is entirely dominated by small $(30-50 \mu \mathrm{m})$ lumps of granular amorphogen. No dinoflagellate cysts were seen. The spore/pollen content is not recorded, but less than five taxa are estimated.

\section{SWC sample $11059 \mathrm{ft}$. (slide S1 925)}

The phyrogen fraction is dominated by spores and pollen (mainly bisaccates) and dinoflagellate cysts. Apart from the bisaccates only two taxa of spores/pollen were seen. At least four taxa of dinoflagellate cysts are present. Important is the recovery of Hystrichogonyaulax cladophora (Engl. finder coord. L 53/4). Resin is present. The kerogen content in general is sparse, about 800 particles/slide. 


\section{Systematical remarks}

Acanthaulax senta Drugg 1978 (or A. areolata (Sarj.) Riley \& Fenton 1982)

Plate 1, fig. 2.

The specimen figured in Fensome 1979 (plate 5/9) has been examined, and it shows a close resemblance to the specimens found in the present investigation. This resemblance, the size $(100 \times 80 \mu \mathrm{m})$ and the apical anastomosing processes make $A$. senta the most likely species.

\section{Energlynia acollaris (Dodekova) Sarjeant 1978}

Plate 1, fig. 6

The epitractal archaeopyle, the bell shaped hypotract with an antapical horn and the low non-fringed paracingular crest are diagnostic characters of this species.

Gonyaulacysta jurassica Deflandre 1938

Plate 1, fig. 1.

Some of the specimens recovered probably belong to $G$. jurassica subsp. adecta Sarjeant 1982.

Hystrichogonyaulax cladophora (Defl.) Stover \& Evitt 1978

\section{Plate 2, fig. 6}

This species is characterized by numerous small bifurcating sutural processes.

\section{Netrelytron stegastum Sarjeant 1961}

Plate 2, fig. 3

Only the specimen has been seen. Because of a somewhat indistinct antapical horn, the specimen recovered might be a Pareodinia ceratophora partly enclosed in amorphogen.

Rigaudella aemula (Defl.) Below 1982

Plate 2, fig. 2

$R$. aemula differs from $R$. filamentosa (Cookson \& Eisenack) Below 1982 in possessing "tree"-like processes whereas the processes of $R$. filamentosa are more "bush"-like. The specimens recovered all show variations of these extremes, and in accordance with the view of R. J. Davey (pers. comm., 1984), all are referred to $R$. aemula.

\section{Wanaea thysanota Woollam 1982}

Plate 1, fig. 4

The specimen figured is the only complete specimen seen. However, owing to the fringed paracingular crest, an unambiguous determination can be made. 


\section{Palynostratigraphy}

The conclusions drawn concerning the dating of the section are based on correlation to palynostratigraphic investigations of English onshore localities (Woollam 1980, Riding 1982, Woolam \& Riding 1983) and to investigations covering the Northwest European region in general (Thusu 1978, Raynaud 1978, Riley \& Fenton 1982). Fig. 2 shows the stratigraphic intervals investigated and summarizes the ranges observed. The common practice among palynologists using the Northwest European standard ammonite zonating as standard zones (orthochronology) is followed (Woollam \& Riding 1983, Riding \& Sarjeant 1984).

With reference to figs. 3 and 4 the following age conclusions are drawn.

\begin{tabular}{|c|c|c|c|}
\hline DINOFLAGELLATE CYSTS & 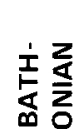 & 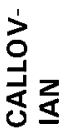 & $\begin{array}{l}\dot{0} \\
\text { or } \\
0 \\
\frac{1}{x} z \\
0 \\
0\end{array}$ \\
\hline Acanthaulax senta & & & $\bar{E}_{4}^{1}{ }^{2}$ \\
\hline Energlynia acollaris & & & \\
\hline Gonyaulacysta jurassica & & & $\overline{\overline{-5}}$ \\
\hline Hystrichogonyaulax cladophora & & & $\frac{\overline{-5}^{4}}{6} 6$ \\
\hline Netrelytron stegastum & & & $\frac{1}{5}{ }^{-1}$ \\
\hline Pareodinia ceratophora & & & $=5_{5}^{4}$ \\
\hline Pareodinia prolongata & & & $\frac{24}{6} 5$ \\
\hline Rigaudella aemula & & & $\frac{\bar{y}_{5}^{4}}{3}$ \\
\hline Scriniodinium crystallinum & & & $\overline{\overline{-5^{4}}}$ \\
\hline Wanaea thysanota & & & $\begin{array}{l}-1 \\
E^{3} \\
E_{5}^{3} \\
5_{5}\end{array}$ \\
\hline Stratigraphic interval investigated & & & $\frac{\overline{-5}^{4}}{6}$ \\
\hline \multicolumn{4}{|c|}{$\begin{array}{l}\text { 1) North-west European Continental Shelf and adjacent areas } \\
\text { Thusu (ed.) (1978) }\end{array}$} \\
\hline \multicolumn{4}{|l|}{ 2) England. Woollam \& Riding (1983) } \\
\hline \multicolumn{4}{|c|}{ 3) Great Britain and central part of the North Sea. Raynaud (1978) } \\
\hline \multicolumn{4}{|l|}{ 4) East Midlands, England. Woollam (1980) } \\
\hline \multicolumn{4}{|l|}{ 5) Cambridgeshire, England. Riding (1982) } \\
\hline \multicolumn{4}{|c|}{ 6) North-west Europe. Riley and Fenton (1982) } \\
\hline
\end{tabular}




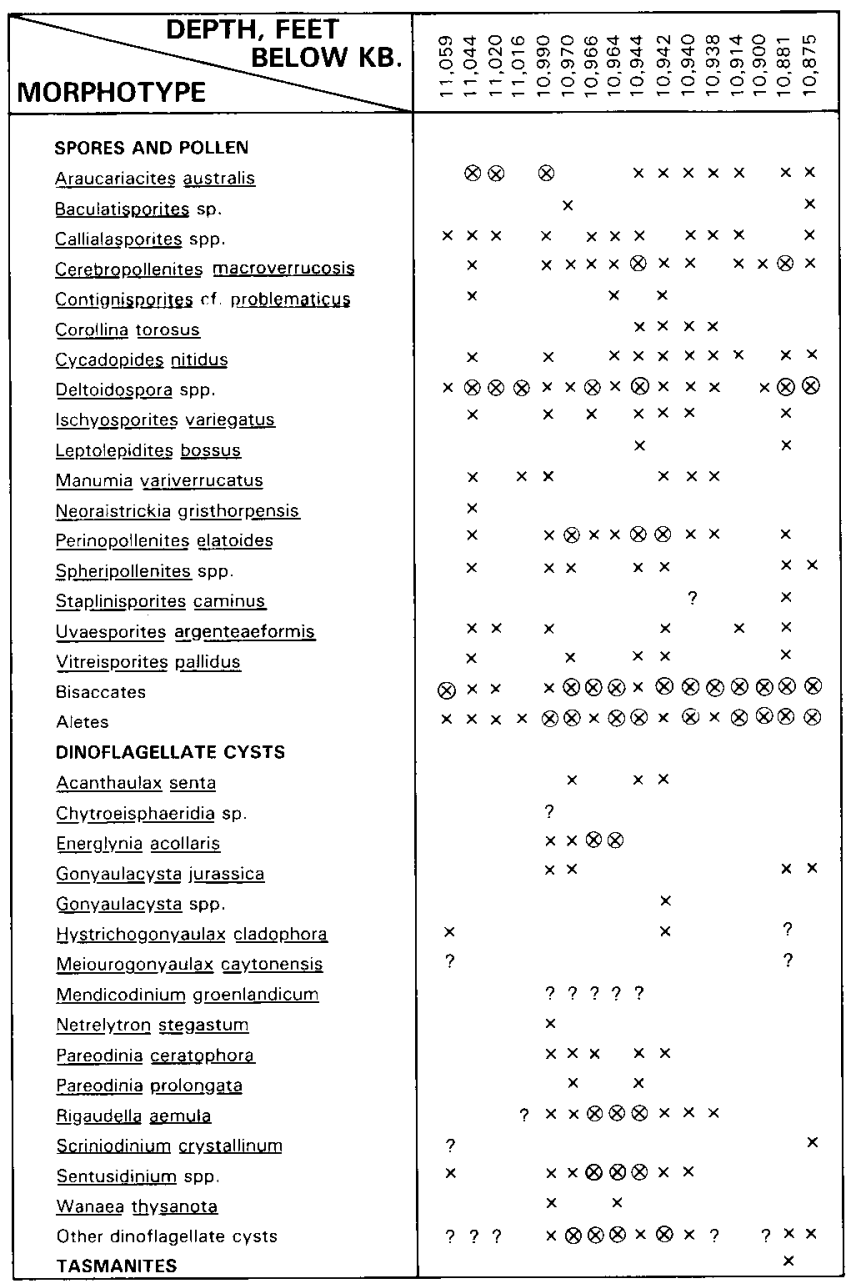

?= Presence doubtful, $x=$ Present, $\otimes=$ More than 2 specimens recovered

Fig. 3. Observed occurrences of dinoflagellate cysts and spores and pollen.
Interval $10990 \mathrm{ft}$. $-11059 \mathrm{ft}$.

Sample $11059 \mathrm{ft}$. contains Hystrichogonyaulax cladophora. This species has its first occurrence in the Callovian, and thus the age of the interval is certainly post Bathonian. As the intervals above are within the Callovian, a Callovian undifferentiated age is assigned to the interval.

It should be noted that the assemblages recorded (spores and pollen as well as dinoflagellate cysts) throughout the investigated section (fig. 3) show no disagreement with the age conclusions drawn above. 


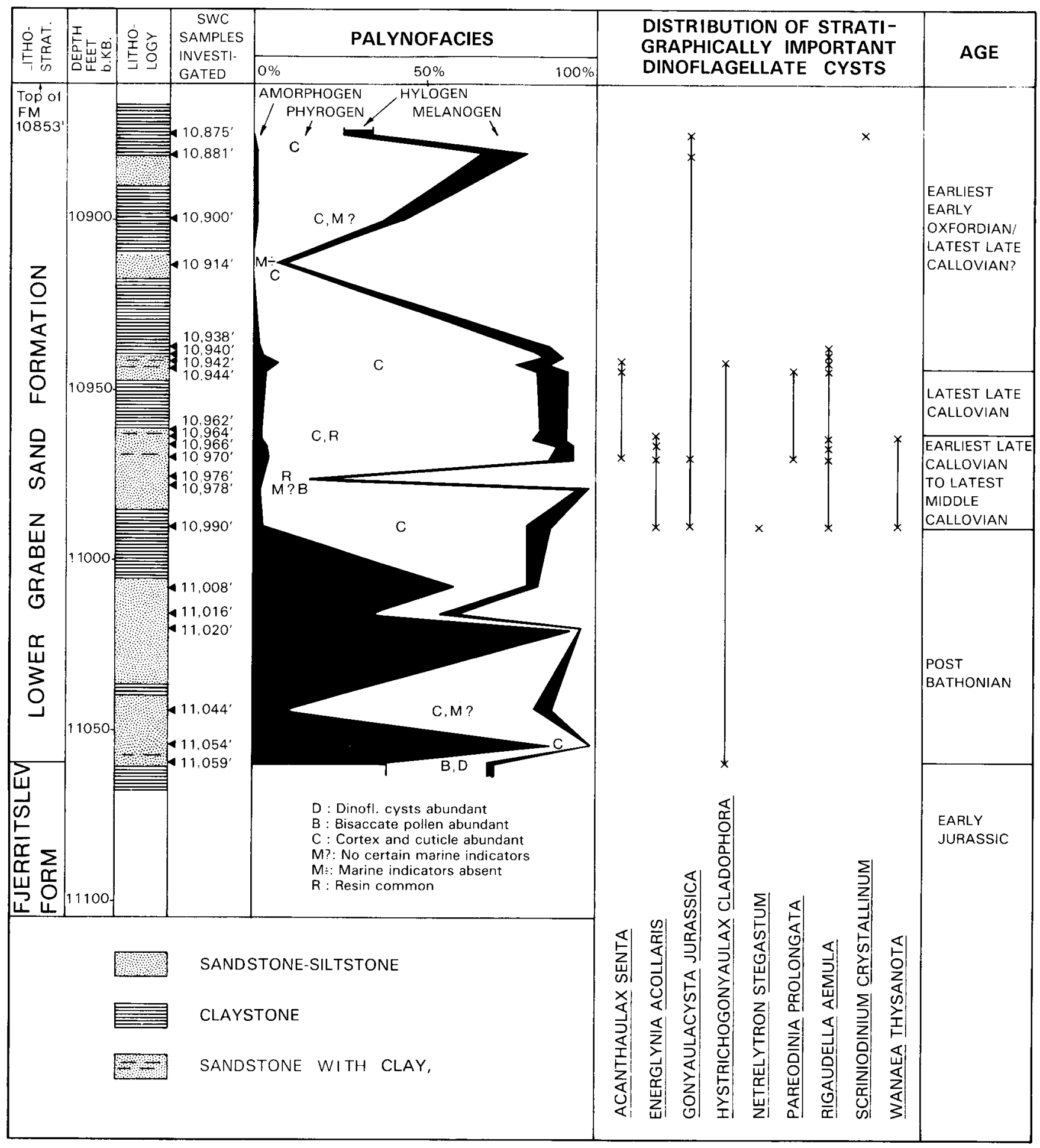

Fig. 4. Distribution of kerogen types and stratigraphically important dinoflagellate cysts, $U-1$ well, interval $10875 \mathrm{ft} .-11059$ ft. b. KB. 


\section{Enviromental evaluation}

\section{Palynofacies analysis}

The distribution of the kerogen-types is shown in fig. 4 .

On the basis of the kerogen composition, the section can be subdivided into an amorphogen-rich lower part $(11008 \mathrm{ft}$. $-11059 \mathrm{ft}$.) and phyrogen-rich upper part (10875 ft. - $10990 \mathrm{ft}$.).

Apart from sample $11044 \mathrm{ft}$, in which phyrogen dominates, amorphogen constitutes $33-93 \%$ of the organic material in the lower part of the section. The content of phyrogen and melanogen varies considerably $(1-40 \%)$. Hylogen is sparsely represented. Unquestionable dinoflagellate cysts are confined to sample $11059 \mathrm{ft}$.

In the upper part of the section, phyrogen accounts for $26-93 \%$ (in average approximately $75 \%$ ). Hylogen is slightly more richly represented than in the lower part. Amorphogen has decreased drastically and is present as a trace only. Melanogen is fairly constant in the interval $10938 \mathrm{ft}$. $-10970 \mathrm{ft}$. $(6-10 \%)$ but is the main constituent in samples $10875 \mathrm{ft}$., $10900 \mathrm{ft}$., 10914 $\mathrm{ft}$. and $10976 \mathrm{ft}$. Dinoflagellate cysts are present in sample $10990 \mathrm{ft}$. in the interval $10938 \mathrm{ft}$. $-10970 \mathrm{ft}$. and in samples $10875 \mathrm{ft}$. and $10881 \mathrm{ft}$.

Throughout the entire section (10875 ft. - $11059 \mathrm{ft}$.) the phyrogen fraction is dominated by cortex and cuticle. Exceptions are samples $10978 \mathrm{ft}$. and $11059 \mathrm{ft}$. in which bisaccates and bisaccates/dinoflagellate cysts, respectively, predominate. Resin is present in several samples, but is especially frequent in samples $10964 \mathrm{ft}$. and $10976 \mathrm{ft}$.

\section{Lithology}

The lithological column (fig. 4) is based on the reference section for the Lower Graben Sand Formation (Jensen et al. 1986).

In broad terms the interval can be subdivided into a lower sandy/silty sub-unit (10960 ft. - $11059 \mathrm{ft}$.) and an upper more clay dominated sub-unit $(10870 \mathrm{ft}$. -10960 $\mathrm{ft}$.$) . This subdivision is in agreement with Michelsen$ (1976).

\section{Depositional environment}

The alternating presence and absence of marine indica- tors (i.e. dinoflagellate cysts) exclude fully marine and distinct terrestrial environments. A marginal marine environment can therefore be assumed. The palynofacies analysis pattern in general support this interpretation as the strong variations in the relative kerogen compositions might reflect the changing depositional environments associated with some marginal marine environments. However, the limited material available makes it difficult to point out a specific marginal marine setting.

Environmental interpretations published for the Lower Graben Sand Formation in the U-1 well concentrate around a fluvial influenced environment (Koch et al. 1982, Koch 1983, Frandsen et al. 1985 and Jensen et al. 1986). The melanogen dominated samples at 10976 $\mathrm{ft}$. and $10914 \mathrm{ft}$. support this interpretation as they might represent high energy environments such as channel sands. Entirely melanogen dominated kerogen assemblages have been demonstrated in palynofacies analyses of Middle Jurassic cored sequences from the Brent Group (Denison \& Fowler 1980 and Perry et al. 1981) and from the Yorkshire deltas (Fisher 1980 and Hancock \& Fisher 1981).

The detailed environmental interpretations of well sections carried out by e.g. Denison \& Fowler 1980, Perry et al. 1981 and Nagy, Dybvik \& Bjærke 1984 are based on cored intervals and employ sedimentology in connection with palynofacies analysis. These are necessary least prerequisites when making environmental interpretations. However, even sporadic palynofacies analysis observations permit presentation of some hypotheses.

Sample $11059 \mathrm{ft}$. contains almost equal amounts of amorphogen, phyrogen and melanogen. The frequent occurrence of bisaccate pollen and dinoflagellate cysts, the near absence of non-bisaccates and the high relative abundance of amorphogen indicate a marine environment. The low frequency of the buoyant cortex and cuticle and the presence of resin and equidimensional melanogen point to relatively high energy conditions. A stratified water column (fresh water/sea water) might produce such an assemblage.

The high relative amorphogen content of the samples at $11008 \mathrm{ft}$., $11016 \mathrm{ft}$., $11020 \mathrm{ft}$. and $11054 \mathrm{ft}$. may infer anoxic conditions, but the granular character of the amorphogen, the modest phyrogen productivity of the samples and the coarse grained sediment are more in accordance with oxidising conditions permitting only a 
small fraction of severely degraded kerogen to be preserved.

Dinoflagellate cysts are present throughout the section above $10990 \mathrm{ft}$, and apart from the lowermost sample (10990 ft.) their greatest diversity and presence in general seem to be confined to the more sandy intervals. Following the model of Denison \& Fowler (1980), the section from $10900 \mathrm{ft}$. to $10970 \mathrm{ft}$. can be interpreted as a predominantly fresh water clay (samples 10900 ft., $10938 \mathrm{ft}$. and $10940 \mathrm{ft}$. showing sparse or no dinoflagellate cysts) interbedded with marine sandy sedi- ments (samples $10942 \mathrm{ft}$, $10944 \mathrm{ft}$, $10964 \mathrm{ft}$., $10966 \mathrm{ft}$. and $10970 \mathrm{ft}$. showing a moderate content of dinoflagellate cysts). Denison \& Fowler (1981) interpret such a relation between lithology and palynology as representing a fresh water lagoon influenced by washover sedimentation. The moderately diverse spore pollen content with no distinct single genus dominance supports the lagoon interpretation. Such an assemblage reflects the total hinterland vegetation in contrast to a flood plain environment assemblage dominated by the local vegetation (commonly Deltoidospora spp.). 


\section{Conclusion}

The dinoflagellate cysts recovered permit a rather detailed age determination of the main part of the section investigated.

The interval $10990 \mathrm{ft}$. $-11059 \mathrm{ft}$. is dated post Bathonian - pre latest Middle Callovian. As the sequence below $11090 \mathrm{ft}$. is dated to the Hettangian-Sinemurian (Michelsen 1976), it is concluded that the Mid Cimmerian Unconformity at the base of the Lower Graben Sand Formation corresponds to a hiatus from the Sinemurian to the Bathonian.

The sequence between sample $10654 \mathrm{ft}$. and sample
$10990 \mathrm{ft}$. covers four Zones (Coronatum, Athleta, Lamberti and Mariae). The age is latest Middle Callovian to earliest Early Oxfordian. The extent of the Coronatum Zone and Athleta Zone can be placed with certainty to the interval $10964 \mathrm{ft}$. $-10990 \mathrm{ft}$. The Lamberti Zone might be restricted to the interval $10944 \mathrm{ft}$. $10964 \mathrm{ft}$.

The alternating presence and absence and diversity variability of the dinoflagellate cyst flora reflect marginal marine conditions. 


\section{Acknowledgements}

Technical facilities were provided by the Geological Survey of Denmark and STRATLAB a.s. (Trondheim, Norway) and the author gratefully acknowledges valuable help and assistance.

Dr. Olaf Michelsen (Geological Survey of Denmark) and cand. scient. Niels Frandsen (Geological Survey of Denmark) gave particularly constructive help and lic. scient Stefan Peasecki (Geological Survey of Greenland) is thanked for his unfailing encouragement and suggestions.
The manuscript was read and improved by Prof. Tove Birkelund (University of Copenhagen), Prof. F. Surlyk (Geological Survey of Greenland) and lic.scient Claus Heilmann-Clausen (University of Aarhus). Help with the English language was given by cand. mag. Hans Christian Enevoldsen (Copenhagen) and Dr. Richard Bromley (University of Copenhagen). 


\section{References}

Below, R., 1982: Rigaudella, ein neues Genus von Dinoflagellatenzysten. Neues Jahrbuch für Geologie und Paläontologie, Monatshefte 3, pp. 137-150.

Blatt, H., Middleton, G. \& Murray, R., 1972: Origin of sedimentary rocks. Prentice-Hall, Inc. London, $634 \mathrm{pp}$.

Bujak, J. P., Barss, M. S. \& Williams, G. L., 1977: Offshore East Canada's organic type and color and hydrocarbon potential. Oil Gas J., 75 (14), pp. 198-202 and 75 (15), pp. 96-100.

Burgess, J. D., 1974: Microscopic Examination of Kerogen (Dispersed Organic Matter) in Petroleum Exploration. Geol. Soc. Am., Spec. Pap. 153, pp. 19-30.

Deflandre, G., 1938: Microplancton des mers jurassiques conservé dans les marnes de Villers-sur-Mer (Calvados). Etude liminaire et considérations générales. Travaux de la Station Zoologique de Wimereux., 13, pp. 147-200.

Denison, C. \& Fowler, R. M., 1980: Palynological identification of facies in a deltaic environment. Proc. Sedimentation of North Sea reservoir rocks, Geilo. Norwegian Petroleum Soc., Oslo sect. 12, $22 \mathrm{pp}$.

Drugg, W. S., 1978: Some Jurassic dinoflagellate cysts from England, France and Germany. Palaeontogr., Abt. B. 168 (1-3), pp. 61-79.

Fensome, R. A., 1979: Dinoflagellate cysts and acritarchs from the Middle and Upper Jurassic of Jameson Land, East Greenland Grønlands Geol. Unders. Bull. 132. pp. 1-98.

Frandsen, N. Hoelstad, T. \& Mikkelsen, N., 1985: Middle Jurassic of the Danish Central Graben. In: Michelsen, O. (ed.): Symposium on Jurassic - Lower Cretaceous of the Danish Central Graben. Danm. geol. Unders., intern. rep. no. 6, pp. 6-19.

Hancock, N. J. \& Fisher, M. J., 1981: Middle Jurassic North Sea deltas with particular reference to Yorkshire. Petroleum Geology of the Continental Shelf of NW Europe. Institute of Petroleum, London, pp. 186-195.

Hoelstad, T., 1986: Palynology and palynofacies analysis of the Middle Jurassic to Lower Cretaceous in the Danish Central Trough. Danm. geol. Unders., (in prep.)

Jensen, T. F., Holm. L., Frandsen, N. \& Michelsen, O., 1986: Jurassic - Lower Cretaceous lithostratigraphic nomenclature for the Danish Central Trough. Danm. geol. Unders., Ser. A

Klement, K. W., 1960: Dinoflagellaten und Hystrichosphaerideen aus dem unteren und mittleren Malm Südwestdeutschland. Palaeontogr. Abt. A. 114, pp. 1-104.

Koch, J.-O., 1983: Sedimentology of Middle and Upper Jurassic sandstone reservoirs of Denmark. Geol. Mijnb., 62 (1), pp. 115129.

Koch, J.-O., Holm. L., \& Michelsen, O., 1982: Jurassic. In: Michelsen, O. (ed.): Geology of the Danish Central Graben. Danm. geol. Unders., Ser. B, 8, pp. 37-45.

Manum, S. B. \& Throndsen, T., 1978: Dispersed organic matter (kerogen) in the Spitsbergen Tertiary. Norsk Polarinstitutt Årbok 1977 pp. 179-187.

Michelsen, O., 1976: Dansk Nords $\emptyset$ U-1. Stratigrafisk inddeling af jura lagserien (2468-3388m) og rhæt (3388-3401m). Danm. geol. Unders. Intern. rep., 5 pp.

Møller, J. J., 1986: Seismic structural mapping of the Middle and Upper Jurassic in the Danish Central Trough. Danm. geol. Unders., Ser. A.
Nagy, J., Dypvik, H. \& Bjærke, T., 1984: Sedimentological and palcontological analyses of Jurassic North Sea deposits from deltaic environments. Journal of Petroleum Geology, 7 (2), pp. 169-188.

Poulsen, N., 1985: Callovian - Volgian dinocyst-stratigraphy of the Danish North Sea area (Central Graben area). In: Michelsen, O. (ed.): Symposiun on Jurassic - Lower Cretaccous of the Danish Central Graben. Dam. geol. Unders., intern rep. no. 6, pp. 20-43.

Parry, C. C., Whitley, P. K. J. \& Simpson, R. D. H., 1981: Integration of Palynological and Sedimentological Methods in Facies Analysis of the Brent Formation. Petroleum Geology of the Continental Shelf of NW Europe. Institute of Petroleum, London, pp. 205-215.

Raynaud, J. F., 1978: Principaux dinoflagellés characteristiques du Jurassique supéricur d'Europe du Nord., Palinologia, 1, pp. 387405.

Reineck, H. \& Singh, I. B., 1980: Depositional Sedimentary Environments. Springer Verlag, Berlin, $549 \mathrm{pp}$.

Riding, J. B., 1982: Jurassic dinocysts form the Warboys Borehole, Cambridgeshire, England. Journal of Micropaleontology, 1, pp. $13-18$.

Riding, J. B. \& Sarjeant W. A. S., 1984. The role of dinoflagellate cysts in the biostratigraphical subdividion of the Jurassic system. In: Michelsen, O. \& Zeiss (ed.): International symposium on Jurassic stratigraphy, Erlangen, Sept 1-8, 1984, Geological survey of Denmark, Copenhagen.

Riley, L. A. \& Fenton, J. P. G., 1982: A dinocyst zonation for the Callovian-Middle Oxfordian succession of Northwest Europe, Palynology, 6, pp. 193-201.

Sarjeant, W. A. S., 1959: Microplankton from the Cornbrash of Yorkshire, Geol. Mag., 96 (5), pp. 329-345.

Sarjeant, W. A. S., 1961: Microplankton from the Kellaways Rock and Oxford Clay of Yorkshire. Palaeont., 4 (1), pp. 90-118.

Sarjeant, W. A. S., 1969: Taxonomic changes, In: Davey, R. J., Downie, C., Sarjeant, W. A. S. \& Williams, G. L.: Appendix to "Studies on Mesozoic and Cainozoic dinoflagellate cysts". Brit. Mus. (Natur. Hist.) Bull. Geol., App. to Suppl. 3. pp. 7-15.

Sarjeant, W. A. S., 1978: A guide to the identification of Jurassic dinoflagellate cysts. Louisiana State Univ., Sch. Geosci., Misc. Publ., no. 78 (1), 107 pp.

Sarjeant, W. A. S., 1983: The dinoflagellate cysts of the Gonyaulacysta group: A morphological and taxanomic restudy. Am. Ass. Strat. Palynologists, Cont. Ser. no. 9, pp. 1-80.

Stover, L. E. \& Evitt, W. R., 1978: Analysis of pre-Pleistocene organic-walled dinoflagellates. Stanford Univ. Publ., Geol. Sci., 15, $300 \mathrm{pp}$.

Thusu, B. (ed.), 1978: Distribution of Biostratigraphically diagnostic Dinoflagellate Cysts and Miospores from the Northwest European Continental Shelf and Adjacent Areas. Continental Shelf Institute Publ. no. 100, $111 \mathrm{pp}$.

Woollam, R., 1980: Jurassic dinocysts from shallow marine deposits of East Midlands, England. Sheffield Univ., Geol. Soc. J., 7 (5), pp. $243-261$

Woollam, R., 1982: Observations of the Jurassic dinocyst genera Energlynia and Wanaea. J. Micropaleontol., 1, pp. 45-52.

Woollam, R. \& Riding, J. B., 1983: Dinoflagellate cyst zonation of the English Jurassic. Rep. Inst. Geol. Sci., 83 (2), pp. 1-42. 


\section{PLATE 1}

Fig. 1. Gonyaulacyusta jurassica Deflandre 1938

(U-1 well, depth $10970 \mathrm{ft}$., sample no 1276, slide D-3, England finder coord. G 29/3).

Fig. 2. Acanthaulax senta Drugg 1978

(U-1 well, depth 10942 ft., sample no. 1273, slide D-3, England finder coord. M 34/3)

Fig. 3. Pareodinia prolongata Sargeant 1959

(U-1 well, depth 10944 ft., sample no. 1274, slide D-3, England finder coord. O 59/4)

Fig. 4. Wanaea thysanota Woollam 1982

(U-1 well, depth $10990 \mathrm{ft}$., sample/slide no. S1 909, England finder coord. H 49/4)

Fig. 5. Pareodinia ceratophora Deflandre

(U-1 well, depth $10966 \mathrm{ft}$., sample no. 1276, slide D-3, England finder coord. V 47/3)

Fig. 6. Energlynia acollaris (Dodekova) Sarjeant 1978 (U-1 well, deptgh 10966 ft., sample no. 1276, slide D-3, England finder coord. N 53/3)

Magnification $\times 1000$ 
PLATE 1

1

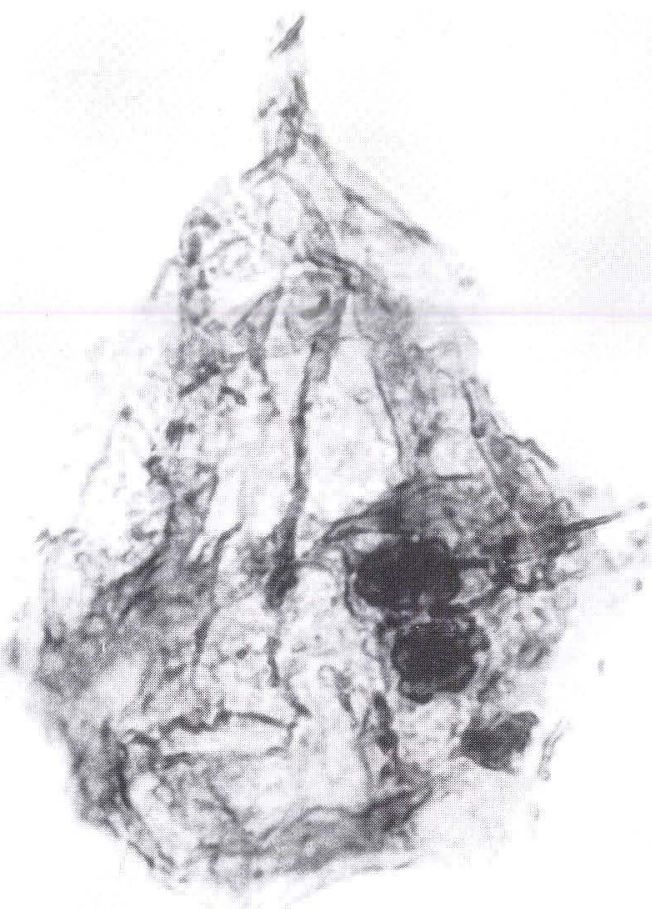

3

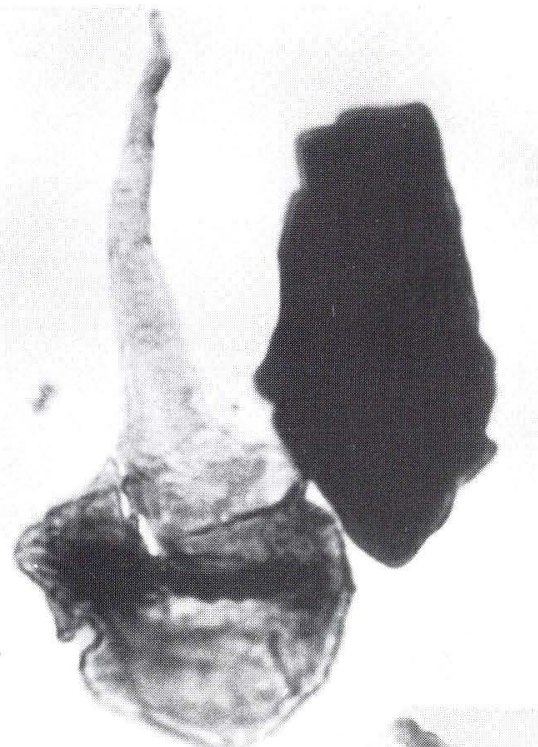

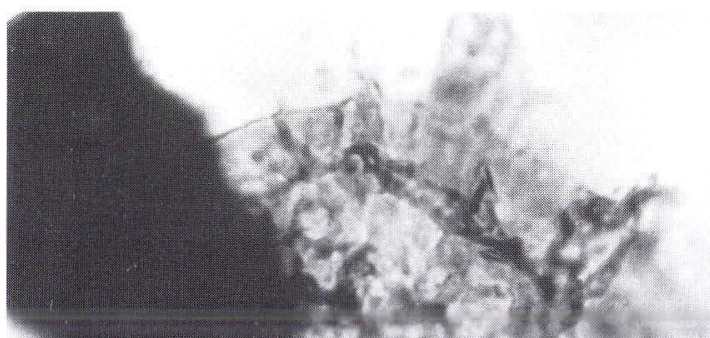
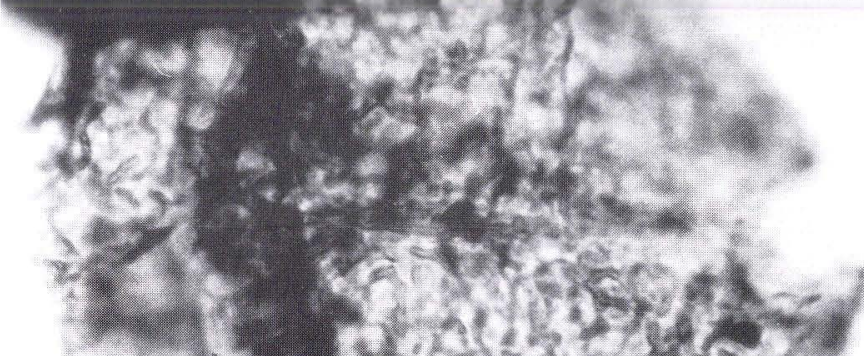

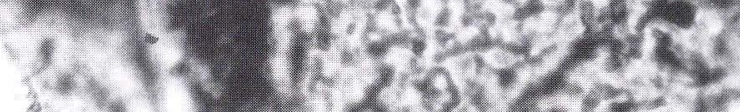

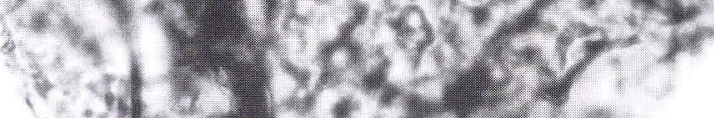

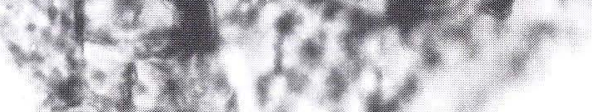

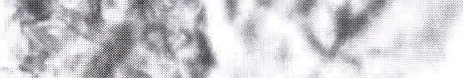
$x^{3}+8$ a $=$
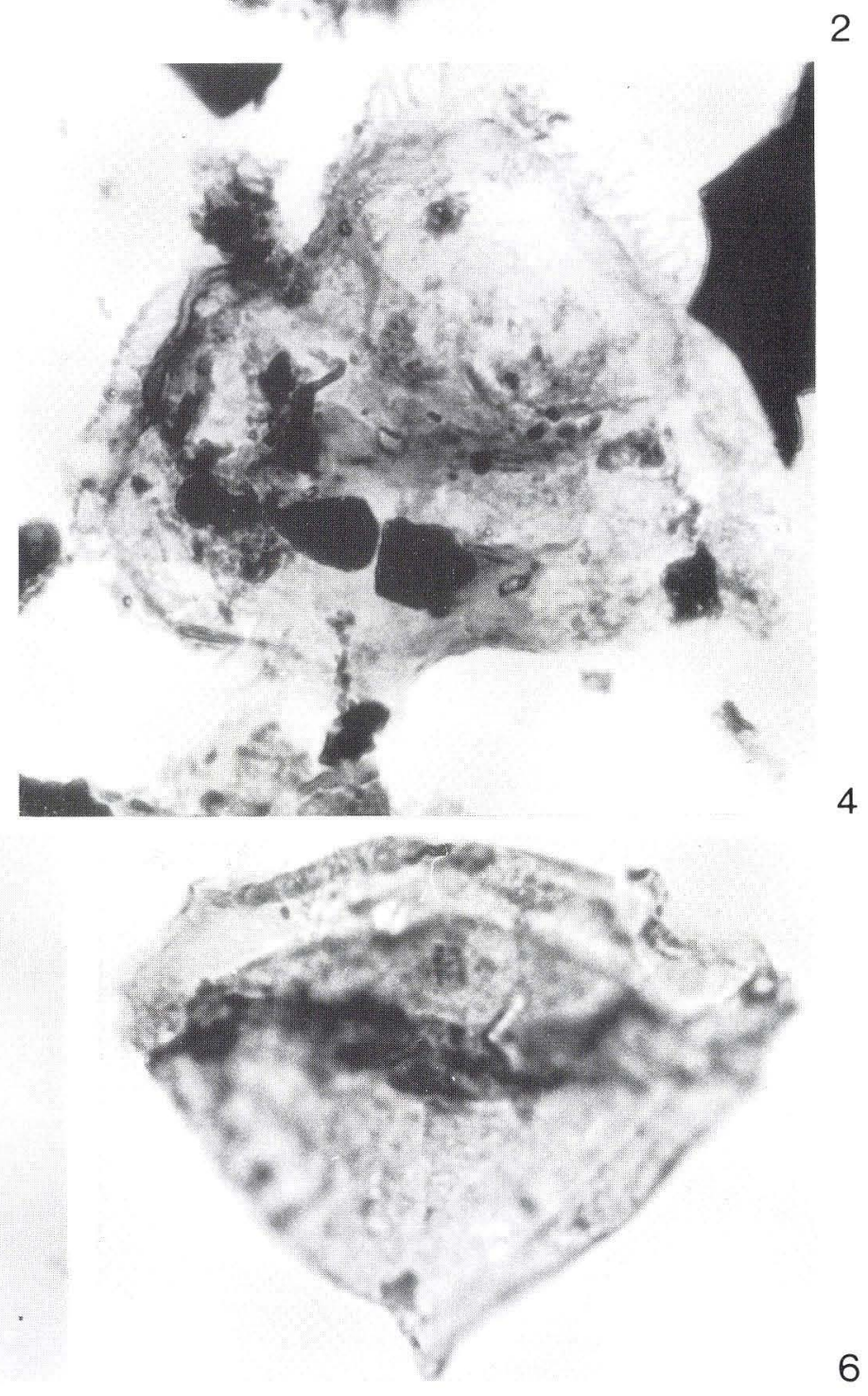


\section{PLATE 2}

Fig. 1. Operculum, Rigaudella aemula (Defl. 1938) Below 1982

(U-1 well, depth $10970 \mathrm{ft}$, sample no. 1277, slide C-2, England finder coord. N 31/1)

Fig. 2. Rigaudella aemula (Defl. 1938) Below 1982

(U-1 well, depth 10942 ft., sample no. 1293, slide D-3, England finder coord. T 44/4)

Fig. 3. Netrelytron stegastum Sarjeant 1961

(U-1 well, depth 10990 ft., sample/slide no. S1 909, England finder coord. R 63/3)

Fig. 4. Cf. Meiourogonyaulax caytonensis (Sarj.) Sarjeant 1969

(U-1 well, depth 11059 ft., sample/slide no. S1 925, England finder coord. O 53/2)

Fig. 5. Scriniodinium crystallinum (Defl. 1938) Klement 1960 (U-1 well, depth 10875 ft., sample/slide no. S1 901, England finder coord. Q 54/3)

Fig. 6. Hystrichogonyaulax cladophora (Defl.) Stover \& Evitt 1978

(U-1 well, depth 10059 ft., sample/slide no. S1 925, England finder coord. L 53/4)

Magnification $\times 1000$ 
PLATE 2

1

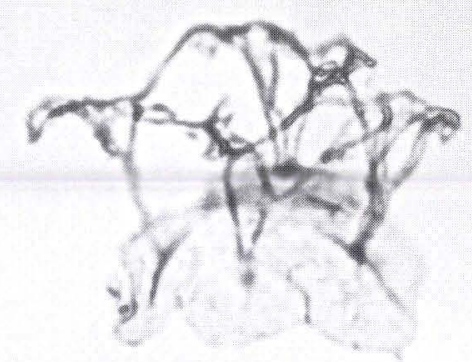

3

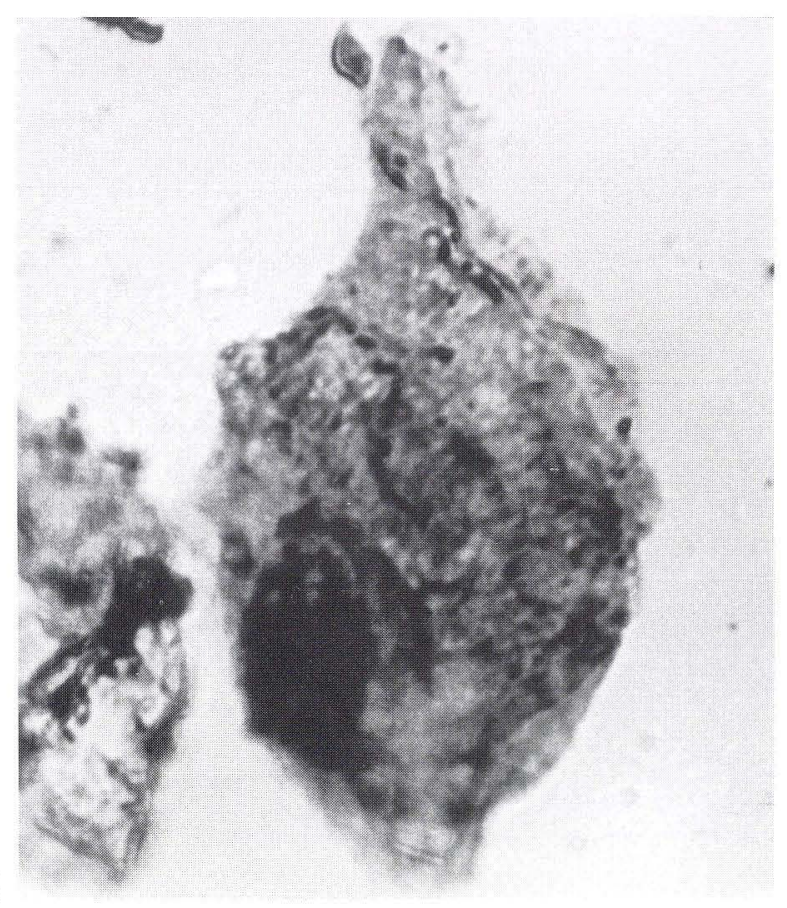

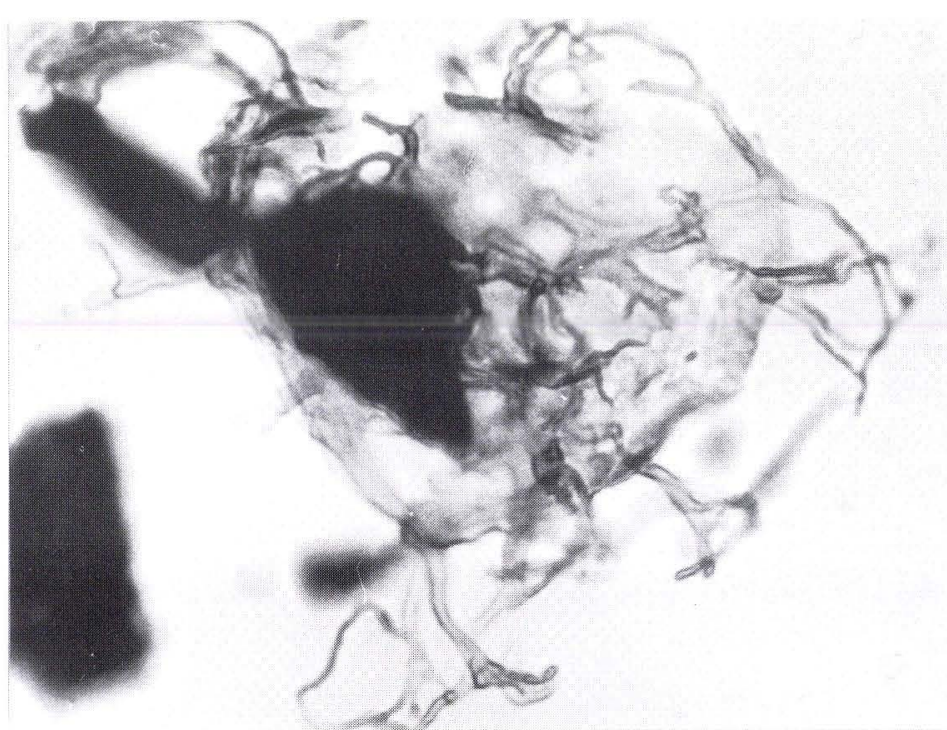

2

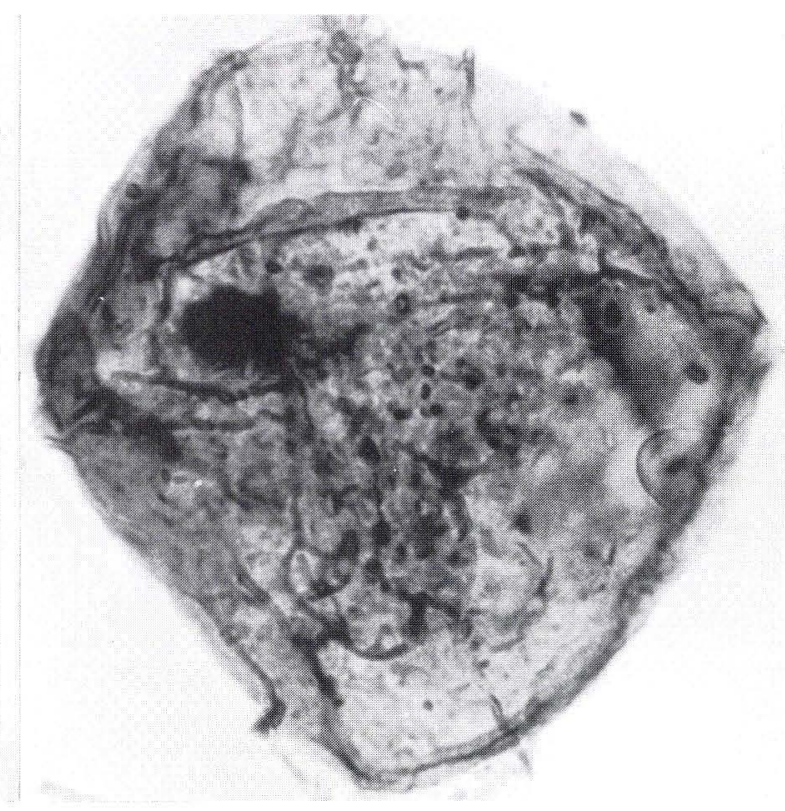

4
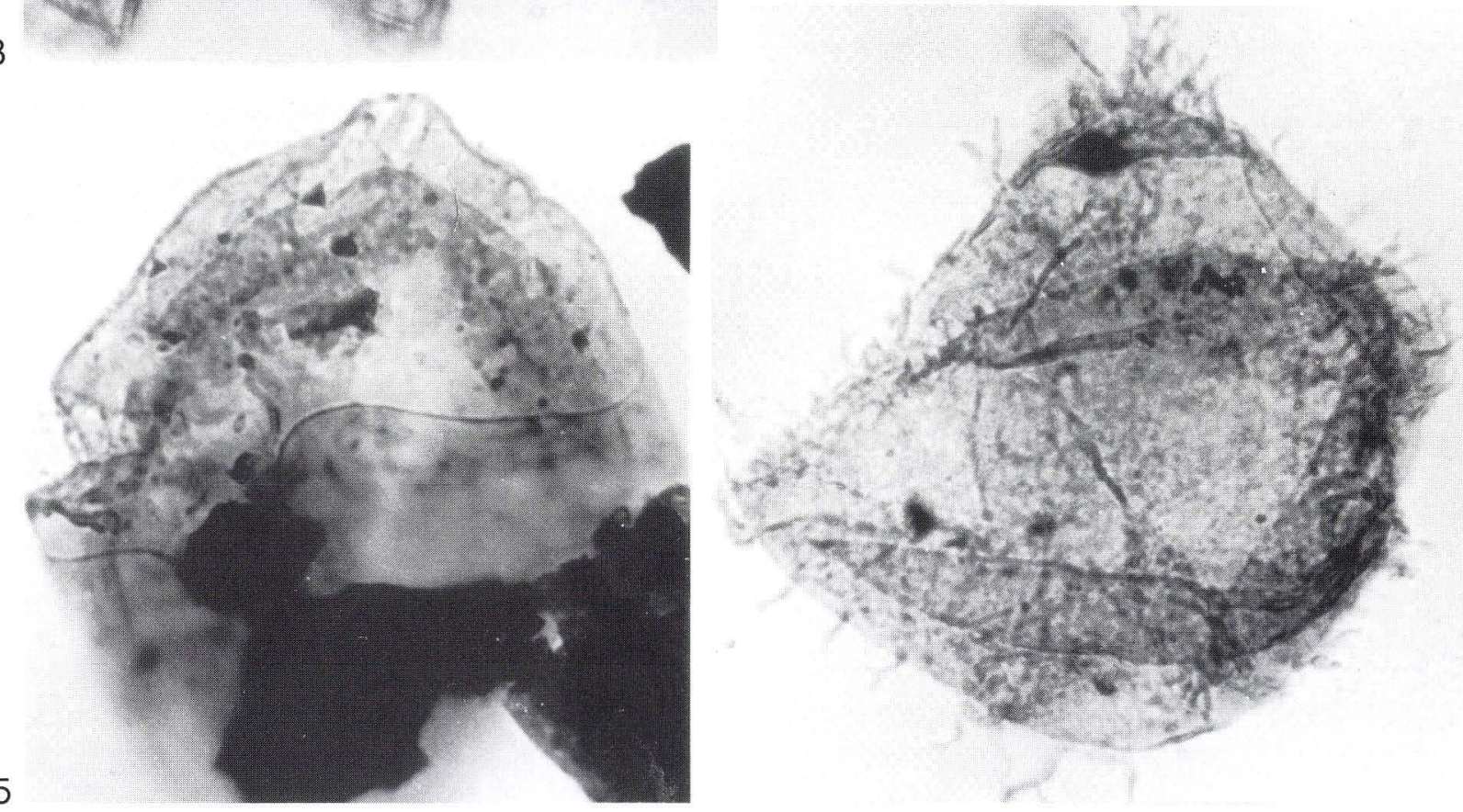
This paper describes the kerogen content and the dinoflagellate biostratigraphy of the Middle Jurassic section of the U-1 well in the Danish Central Trough, North Sea. 